\title{
Retratação
}

A equipe editorial da Revista Estudos Feministas comunica a publicação formal de retratação parcial do artigo:

DALCOL, Mônica Saldanha; ALÓS, Anselmo Peres. "O mundo da vida e o mundo do texto em Úrsula, de Maria Firmina dos Reis". Revista Estudos Feministas, v. 27, n. 1, e50550, 2019. https://dx.doi.org/ 10.1590/1806-9584-2019v27n150550

Desde que foi comprovada a necessidade de retirada da nota de rodapé número 10.

Prof. Dra. Cristina Scheibe Wolff

Prof. Dra. Mara Coelho de Souza Lago

Prof. Dra. Luzinete Simões Minella

Prof. Dra. Tânia Regina de Oliveira Ramos

Editoras 


\section{O mundo da vida e o mundo do texto em Úrsula, de Maria Firmina dos Reis}

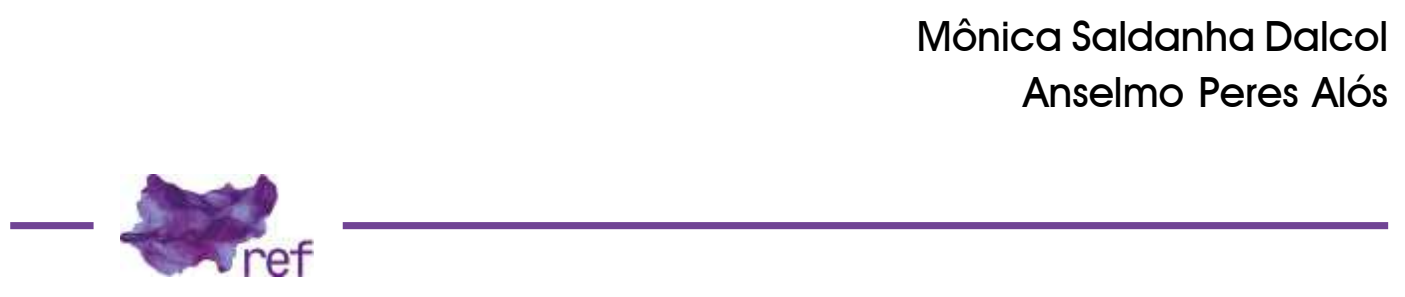

Resumo: O romance Úrsula, de Maria Firmina dos Reis (2004), teve sua primeira publicação em 1859. Ele revela sua magnitude por dois aspectos: o primeiro, por ter sido o primeiro romance de autoria afrodescendente da literatura brasileira; o segundo, por ter sido o primeiro romance abolicionista escrito no Brasil. Nele, Maria Firmina dos Reis faz da escrita literária o palco da voz dos seus antepassados, onde os próprios sujeitos escravizados retratam, sob seus próprios pontos de vista, a questão da escravidão. A escrita de Maria Firmina dos Reis questiona a tradição escravocrata e patriarcal, marcada pela estigmatização e pela subalternização das comunidades afro-brasileiras e, consequentemente, por seu silenciamento durante séculos. Tendo em vista esses aspectos, a análise terá como pano de fundo a distinção desenvolvida por Paul Ricoeur em Do texto à ação: ensaios de hermenêutica (1989): o mundo do texto e o mundo da vida, assim como a discussão acerca da noção de mundo proposta por Antoine Compagnon em O demônio da teoria (2014).

Palavras-chave: Úrsula; Maria Firmina dos Reis; literatura afro-brasileira; mundo e ficção; autoria feminina

The World of Life and the World of the Text on Ursula by Maria Firmina dos Reis

Abstract: The novel Ursula, by Maria Firmina dos Reis, had its first publication in 1859. It reveals the magnitude of two aspects: the first, for being the first novel by an afro-descendant's authorship in Brazilian literature; the second is that it was also the first abolitionist novel written in Brazil. In it, Maria Firmina dos Reis makes of the literary written a voice stage of her ancestors, in which the enslaved individuals themselves portray under their own views the issue of slavery, from their homeland to the route to get to Brazil. Thus, the writing of Maria Firmina dos Reis sets textually a slave owner and patriarchal tradition, marked by stigma and social subordination of the Afro-Brazilian communities and in consequent, their muting for centuries. Considering these aspects, our analysis will have as a background the ricoeurian distinction of the world of the text and the world of the life, as well as the notion of the world and the reader in this novel, from the discussions proposed by Antoine Compagnon in O demônio da teoria. Therefore, our work will focus on the analysis of the novel from these conceptualizations.

Keywords: Úrsula; Maria Firmina dos Reis; Afro-descendant Literature; World and Fiction; Female Authorship

\section{Introdução: ética, violência e representação}

O contexto da literatura brasileira produzida no século XIX tem sido reconstruído graças ao empenho de algumas pesquisadoras, como, por exemplo, Zahidé Muzart (1999), responsável por organizar o compêndio Escritoras Brasileiras do Século XIX: Antologia (posteriormente, este se tornaria o primeiro volume, ao qual se somariam mais dois). O trabalho de resgate e da revisão crítica das autoras que produziam no século XIX, que por uma série de fatores foram "esquecidas" e não constam nos manuais tradicionais de Literatura, tem proporcionado um novo olhar da literatura brasileira, mostrando-nos que há um universo cultural de produção de autoria feminina que precisa ser conhecido. No caso da autoria feminina afro-brasileira, a situação de silenciamento é ainda maior, visto que, tradicionalmente, a figura do(a) negro(a) na literatura brasileira ocupa o lugar de objeto, sendo representado(a) a partir de uma visão estereotipada. É Maria Firmina dos 
Reis que consegue romper essa barreira, por um lado, por ser uma negra escrevendo em pleno século XIX, e, por outro, por ter concedido, pela primeira vez na literatura, voz a uma narradora negra, na figura de Mãe Suzana. Em um século marcado pelo sistema escravagista, Maria Firmina constrói uma narrativa inovadora para a época, uma narrativa em que os personagens negros fogem da estereotipização, configurando, desse modo, uma escrita comprometida com o caráter ético, a partir do momento que a narrativa presente em Úrsula inaugura e legitima os personagens negros(as) enquanto sujeitos.

O romance Úrsula (2004), de Maria Firmina dos Reis (1825-1917), traz a história de amor entre Úrsula, a personagem central, e Tancredo, tendo como pano de fundo a temática do período sombrio da escravidão no Brasil. A narrativa pretende recuperar esse período histórico, fazendo esforço para reinterpretá-lo pela ótica dos sujeitos que foram escravizados, entre eles, a voz mais significativa da narrativa, "Mãe Susana", que oscila seu discurso entre a recuperação da memória a partir de sua própria condição atual, enquanto "escravizada".

A narrativa caracteriza a "atitude política" da escritora Maria Firmina dos Reis, em que a ficção mostra-se como palco de denúncias, principalmente com relação às injustiças vivenciadas pelas mulheres e pelos sujeitos escravizados no século XIX. De certo modo, a autora trata de modo ficcional questões que dizem respeito à ética, como a noção de humanidade (no caso do romance, uma irmandade possível entre brancos e negros).

A tradicional perspectiva ética centrada na racionalidade apresenta uma visão reducionista da vida moral, tendo em vista que a proposta intelectualista' deixa de lado o contexto da vida prática, onde não encontramos nenhuma transparência em relação às escolhas que os seres humanos precisam fazer para terem uma vida moral. Além disso, do ponto de vista propriamente ético, historicamente tudo que escapa à categorização da norma masculina, branca, heterossexual, judaico-cristã e eurocêntrica costuma ser excluído de um sistema moral, colocando em cheque a idealização universal, uma vez que deixa à margem do sistema moral uma série de indivíduos. ${ }^{2}$

Portanto, se concordamos que a filosofia moral diz respeito ao modo efetivo como os seres humanos de fato agem, e que necessariamente ela tem algo a ver com a vida prática dos indivíduos, se faz necessário que sejamos capazes de (ou, ao menos, que estejamos dispostos a) analisarmos o comportamento humano como de fato ele se mostra. Historicamente, encontramos um fluxo de situações e adversidades sociais que fizeram com que "as minorias" não tivessem nenhuma garantia de ser (ou mesmo de se tornar) um conjunto de sujeitos ativos de uma comunidade moral, nem como seres atuantes nem como seres passíveis de dignidade, pressuposto básico para falarmos em comunidade moral. Quais os tipos de desvios utilizados por Maria Firmina dos Reis para incluir, em um sistema ético, sujeitos que historicamente foram empurrados para fora e para além desse mesmo sistema? Judith Butler, em sua obra recentemente traduzida Relatar a si mesmo: crítica da violência ética (2015), busca resolver o problema monumental da ética prática: como devemos agir ou o que devemos fazer para sermos sujeitos éticos? A resposta de Butler parte da premissa de que só é possível encontrar uma saída para a questão a partir de um novo sentido para o conceito de "sujeito" através do conhecimento do mundo social que nos precede. A filósofa abandona o sonho moderno segundo o qual os sujeitos seriam capazes de se apreenderem inteiramente, como imaginaram os filósofos modernos. Para a filósofa, o sujeito é marcado pela opacidade e pela vulnerabilidade, e a única possibilidade de moralidade seria a partir da "experiência do outro, sob a condição de termos suspendido o juízo" (2015, p. 23), o que possibilitaria, segundo ela, uma real reflexão acerca da "humanidade do outro".

A relação entre a ética tradicional e a violência ocorre, segundo Butler, exatamente no momento em que se pretende definir previamente um enquadramento de possibilidades de reconhecimento, isto é, só os indivíduos que responderão ao enquadramento a priori estarão incluídos em um sistema moral, terão o seu reconhecimento garantido. A ideia central de Butler é que o outro deve ser reconhecido enquanto outro e, mesmo assim, ter o seu reconhecimento garantido. Com essa premissa, temos uma abertura para articular as categorias como ética, gênero, negritude e violência, o que era impossível em um modelo de ética tradicional, por exemplo. Partindo dessas categorias filosóficas, acreditamos que podemos, de certa forma, encontrar em Úrsula uma configuração dessas categorias no plano da enunciação literária, seja a partir da questão de gênero, levando em consideração a autoria feminina no século XIX, seja pelo modo inovador com que a narrativa se desenvolve, pela primeira vez, dando voz e,

\footnotetext{
' Em Os elementos da Filosofia Moral, James Rachels (2006) apresenta uma abordagem da moralidade pautada pela noção de obrigação. Sua principal preocupação é enfocar os elementos fundamentais que se vinculam ao desenvolvimento de uma teoria moral. Dentro dessa teoria moral, a fonte fundamental da moralidade reside na pretensão de ser o mais racional e cauteloso possível, e o agente moral é aquele capaz de apresentar razões para suas suposições ou crenças. Rachels propõe uma "concepção mínima de moralidade" como uma espécie de capacidade racional de reconhecer as razões para exercer a ação moral: "amoralidade é, minimamente, o esforço em guiar a conduta do indivíduo por meio da razão" (RACHELS, 2006, p.15). Para isso, deve-se ter em mente que os julgamentos morais devem ter, na sua base, razões válidas, o que exige uma determinada imparcialidade do indivíduo.

2 Optamos por utilizar indivíduos ao invés de sujeitos, já que são seres humanos que estão excluídos do sistema moral.
} 
consequentemente, reconhecimento, através do modo como os personagens são construídos. Sendo assim, podemos encontrar no plano ficcional o reconhecimento que historicamente foi negado às mulheres negras, tanto do ponto de vista literário como do ponto de vista social.

\section{Vozes afrodescendentes, escritas subalternizadas: o mundo do texto e o mundo da vida em Úrsula}

O romance Úrsula (1859), escrito por Maria Firmina dos Reis, publicado ainda no período escravocrata no Brasil, revela sua grandeza por ter sido o primeiro romance a retratar personagens negros e negras de outro ponto de vista, de um ponto de vista "interno"; isto é, pela primeira vez na literatura brasileira, eles não são retratados como indivíduos resignados e marcados pela excessiva estereotipação. A magnitude do romance pode ser conferida a partir de duas premissas: 0 argumento autoral (ele foi o primeiro romance de autoria afrodescendente da Literatura Brasileira) e o argumento da precedência histórica (ele também foi o primeiro romance abolicionista escrito no Brasil, apesar da historiografia sempre ter afirmado que o primeiro romance abolicionista foi $A$ escrava Isaura, de Bernardo Guimarães, 2011).

O romance Úrsula possui o seu caráter inovador com relação aos outros romances do período por trazer no seu enredo personagens negros e negras. Porém, não é apenas esse fator que faz com que ele seja inovador. Em Úrsula, pela primeira vez na história da literatura brasileira, nós temos a voz de uma narradora escravizada, a personagem Mãe Suzana. Apesar de o romance partir de um fenômeno histórico vergonhoso e obscuro do regime escravocrata, a autora consegue, através do recurso ficcional, ultrapassar essa dimensão histórica.

A autora retira a mordaça do silenciamento a partir do momento que possibilita que esses personagens tenham voz e, além disso, sejam caracterizados como sujeitos. Nesse sentido, os personagens negros(as) são colocados no mesmo patamar que os personagens brancos, apesar de toda conjuntura escravocrata, fazendo com que a escrita de Maria Firmina dos Reis seja completamente transgressora para o período, na medida em que ela vai na contramão da maioria dos escritos da época, marcados pelo tom ufanista, em que o nacionalismo patriótico está presente (como, por exemplo, em Gonçalves Dias e em José de Alencar). O romance Úrsula supera esse padrão ao articular a voz dos personagens negros e negras à condenação explícita à escravidão enunciada pela voz narrativa. A articulação presente no romance entre a dimensão ficcional e o mundo "real", explicitamente contido, no romance será compreendida a partir da visão desenvolvida por Paul Ricoeur (1989), a partir dos conceitos de mundo da vida e mundo do texto. De que modo essas duas dimensões estão presentes na escrita de Maria Firmina dos Reis?

Paul Ricoeur é conhecido na história da filosofia pela forma como desenvolve seu pensamento filosófico, mantendo uma posição dialógica com a tradição filosófica, não apenas no que concerne à fenomenologia, mas também à filosofia analítica, colocando em confronto essas duas áreas tão distintas e que tradicionalmente não se relacionam de forma pacífica. Assim, é a partir da retomada de grandes mestres (como, por exemplo, Aristóteles, Kant, Husserl e Gabriel Marcel) que Ricoeur discute e elabora seu próprio pensamento, tendo como ponto de partida a reflexão sobre a existência concreta do indivíduo. ${ }^{3}$ O ser humano, para Ricoeur (1989), é interpretado, sob o ponto de vista ontológico ${ }^{4}$, como um ser dotado de capacidades não apenas a partir da racionalidade (como pensou grande parte da tradição filosófica ${ }^{5}$ ), mas como um ser capaz de narrar, de agir, de escolher, e de ser responsável por suas ações. Entre tantas outras características, está a noção de texto e a sua dimensão prática - a relação entre o chamado mundo do texto e o mundo da vida ultrapassa o plano linguístico para materializar-se na vida prática.

Antoine Compagnon, no capítulo III de O demônio da teoria (2014), analisa e problematiza as possíveis relações entre a literatura e a realidade, já colocada pelos antigos (a partir de Aristóteles) e pelos modernos (a partir de Erich Auerbach). Para Compagnon, a teoria literária não mediu esforços para tentar resolver um problema gigantesco: a relação entre a literatura e a realidade. Segundo Compagnon, a teoria literária instituiu a autonomia da literatura em relação ao mundo. A análise das relações entre a literatura e o mundo teve início a partir da abordagem teórica partindo do autor e sua intenção. Compagnon enfatiza as duas posições clássicas e opostas entre si, o "dialogismo" ou a "intertextualidade", que substituíram a realidade constituída "como referente da literatura, a própria literatura" (2014, p.96). Nossa atenção não será voltada para uma análise detalhada das tensões teóricas levantadas por Compagnon. Para o presente trabalho, iremos nos concentrar no conceito de mímese, visto que o nosso objetivo é a apropriação do termo pela hermenêutica de Ricoeur.

\footnotetext{
${ }^{3}$ Essa tradição de analisar e problematizar a existência dos seres humanos teve como precursores, primeiramente, Schopenhauer e Nietzsche, a partir da Filosofia da vida e, posteriormente, na Filosofia contemporânea, a partir da corrente do existencialismo.

${ }^{4}$ O problema do "ser" teve início com Parmênides, na Grécia Antiga; porém, na filosofia contemporânea, ele ressurge, já que constitui a própria essência da filosofia.

${ }_{5}^{5} \mathrm{Um}$ dos grandes exemplos desta tradição é o cogito cartesiano.
} 
O conceito de mímese na tradição filosófica grega possui duas abordagens distintas. Uma negativa, a partir de Platão (2000), no seu livro A República, onde a mimeses é vista estritamente como imitação.

Platão (1972), em seu diálogo Sofista, diferencia a mímese, atividade mimética, de dois modos distintos: a imitação é cópia e simulacro. Enquanto a primeira se detém na reprodução, e por isso não é perfeita como as ideias arquetípicas, o segundo modo, "simulacro", é a atividade mimética desenvolvida pelos artistas de modo geral, é a cópia da cópia, isto é, os artistas reproduzem o que já se encontra no mundo sensível, não no mundo inteligível, sendo, portanto, a cópia de algo que em si já é uma cópia. Desse modo, a arte estaria sempre distante do verdadeiro conhecimento por manter-se apenas na reprodução de cópias.

Outra importante abordagem da mímese, positiva, encontra-se na Poética, de Aristóteles (2008), a arte mimética sendo relacionada à interpretação. É essa arte que reproduz ações e encena gestos. Segundo Compagnon (2014), a mímese define o que compreendemos por literatura, pelo menos até o século XX. Os filósofos entendiam a arte e a literatura como imitação da natureza, porém, houve mudança de sentido no termo a partir da filosofia aristotélica, para quem a mímese era verossimilhança com o sentido natural.

Parece ter havido para a poesia em geral duas causas, causas essas naturais. Uma é que imitar é natural nos homens desde a infância e nisto diferem dos outros animais, pois o homem é o que tem mais capacidade de imitar e é pela imitação que adquire os seus primeiros conhecimentos; a outra é que todos sentem prazer nas imitações. Uma prova disto é o que acontece na realidade: as coisas que observamos ao natural e nos fazem pena agradam-nos quando as vemos representadas em imagens muito perfeitas como, por exemplo, as reproduções dos mais repugnantes animais e de cadáveres. A razão disto é também que aprender não é só agradável para os filósofos mas é igualmente para os outros homens, embora estes participem dessa aprendizagem em menor escala. (ARISTÓTELES, 2008, p.42).

Para Aristóteles (2008), mímese mantém um elo com a arte dramática. A poética aristotélica não objeto acentua nunca o imitado ou representado, mas o objeto imitador ou representado, a técnica da representação, a sua própria estrutura do mythos. Desse modo, como afirma Compagnon, a mímese aristotélica não visava ao estudo das relações entre a literatura e a realidade (tal relação será postulada somente pela modernidade), mas à produção da ficção poética verossímil (2014, p.101). Isto é, ela é a representação das ações humanas a partir da linguagem; desse modo, ressalta o crítico, Aristóteles estava interessado no "arranjo narrativo".

A mímese como reconhecimento é conhecida na filosofia hermenêutica como uma terceira leitura ${ }^{6}$ da Poética de Aristóteles (2008). Ao contrário do que pensava Platão, Aristóteles não via a mímesis como cópia das ideias verdadeiras, mas sim com um "conhecimento próprio ao homem", como destaca Compagnon:

A mímese é, pois, conhecimento, e não cópia ou réplica idênticas: designa um conhecimento próprio ao homem, a maneira pela qual ele constrói, habita o mundo. Reavaliar a mímese, apesar do opróbio que a teoria literária lançou sobre ela, exige primeiro que se acentue seu compromisso com o conhecimento, e daí com o mundo e a realidade. (COMPAGNON, 2014, p.124).

Um dos principais pensadores que retomou o conceito de mímese foi Paul Ricoeur, a partir de sua articulação entre o mundo do texto e o mundo da vida, que só é possível através da narrativa. Como entende Ricoeur, o texto é a unidade linguística por excelência, e torna-se assim a mediação apropriada entre o vivido temporal e o ato narrativo (Paul RICOEUR, 1989, p.25). Cada texto abarca em si uma proposta de mundo que deve ser interpretada pelo leitor, como afirma o próprio filósofo:

O que se deve, de fato, interpretar num texto é a proposta de mundo, de um mundo tal que eu possa habitar e nele projetar um dos meus possíveis mais próprios. É aquilo a que eu chamo o mundo do texto, o mundo próprio a este texto único. (RICOEUR, 1989, p.122).

Na proposta de Ricoeur, cada texto traz uma proposta de mundo; esse postulado faz-se visível no romance de Maria Firmina dos Reis, onde escrita afro-brasileira de autoria feminina traz as marcas do sistema escravocrata. Porém, mesmo que haja influência do mundo histórico no romance, a escritora consegue ultrapassar essa dimensão, principalmente quando rompe paradigmas e scripts narrativos da época, ao dar voz aos indivíduos escravizados e, mais que isso, ao se apropriar dos valores morais cristãos para propagar o seu "ideário" de reivindicar a humanidade e a liberdade daqueles que foram escravizados:

Senhor Deus! Quando calará no peito do homem a tua sublime máxima-ama a teu próximo como a ti mesmo- e deixará se oprimir com tão repreensível injustiça ao seu semelhante!...

\footnotetext{
${ }^{6}$ As duas outras vias de leitura estavam concentradas na defesa de que a literatura imitava o mundo, ou na crítica de que ela não possuía uma exterioridade, principalmente a partir da compreensão da mimesis enquanto uma técnica de representação.
} 
Aquele que também era livre no seu país... Aquele que é seu irmão?! E o mísero sofria, porque era escravo, e a escravidão não lhe embrutecera a alma porque os sentimentos generosos, que Deus Ihe implantou no coração, permaneciam intactos, e puros como sua alma. Era infeliz, mas era virtuoso. (REIS, 2004, p.23).

O mundo próprio do texto que a escritora apresenta não corresponde ao mundo da vida, principalmente quando se tem em mente o contexto brasileiro do século XIX. A narrativa de Maria Firmina dos Reis configura, através do discurso literário, um mundo ficcional em que os indivíduos possam ser efetivamente sujeitos, isto é, eles(as) têm a garantia da voz, de reivindicar para si a humanidade que foi extinta através do sistema escravocrata. A ficção possibilita um mundo possível onde esses sujeitos possam habitar. O romance de Maria Firmina dos Reis reconfigura, inclusive, a própria noção de identidade nacional, tão em voga no romantismo brasileiro, já que oferece uma nova proposta de nação que deve reconhecer os seus ancestrais escravizados, de origem africana.

A compreensão de Ricoeur sobre o conceito de mundo do texto não diz respeito à linguagem ordinária; pelo contrário, ele fornece uma espécie de distanciamento que deve ser entendido como outra referência ao real, possibilitada por esse mundo. Essa distância é introduzida pela capacidade ficcional na apreensão da realidade, oferecendo novas possibilidades de ser-nomundo:

Já dissemos que uma narração, um conto, um poema não existem sem referente. Mas este referente está em ruptura com o da linguagem cotidiana; pela ficção, pela poesia, abrem-se novas possibilidades de ser-no-mundo, na realidade cotidiana; ficção e poesia visam [a] o ser, já não sob a modalidade do poder-se. Por isso mesmo, a realidade cotidiana é metamorfoseada graças ao que poderíamos chamar as variações imaginativas que a literatura opera no real. (RICOEUR, 1989, p.122).

As variações imaginativas, segundo o filósofo, só são possíveis através da literatura; é por essa via de acesso que os seres humanos conseguem, após ultrapassar o mero plano da linguagem cotidiana, encontrar novas possibilidades de se reinventarem no mundo. O que permite a relação entre a ficção e a realidade, tornando inteligível determinada ação, é a coerência da narrativa, que faz com que as ações no mundo sejam passíveis de leitura como um texto. $O$ texto, dentro do horizonte de Ricoeur, deve ser compreendido como algo mais que uma simples estruturação de frases, pois ele exige que o paradigma da interpretação seja transposto para o âmbito da ação, fazendo com que o texto e a vida se relacionem.

A noção de narrativa desenvolvida por Ricoeur resulta, por um lado, da sua interpretação da Poética de Aristóteles e, por outro, da noção de tempo presente nas Confissões de Santo Agostinho. Um texto converte-se em narração através da "composição verbal", que na linguagem aristotélica corresponde ao termo mythos, também entendido como fábula ou intriga. A inteligibilidade da intriga é sustentada pela sua organização sistemática, isto é, há alguns fatos e ações que são descritos de modo que exista certa ordenação (o que faz com que a história que esteja sendo narrada seja completa e permita que o leitor possa compreendê-la). Essa ordenação é dada pela estrutura da história: início, meio e fim. Essa concepção triádica está presente em Aristóteles, e Ricoeur dela se apropria. Com relação à estrutura de um romance, por exemplo, para que haja sentido e compreensão, deve-se ter em mente a dimensão temporal. Essa mesma dimensão, triádica, para o filósofo, encontra-se nas ações humanas: início, meio e fim, a mesma ordenação configurante que dá sentido à história narrada - e agora à ação realizada. Uma narrativa, segundo Ricoeur, é mais que um simples relato de alguns determinados fatos: ela é configurada de uma forma que pode ser reconhecida e compreendida, o que também vale para as ações humanas - já que elas também podem ser reconhecidas e compreendidas.

\section{A mímese: ficção criadora}

A ficção, na filosofia de Paul Ricoeur (2000), é elevada a um patamar de suma importância: ela não diz respeito apenas a uma dimensão emocional e afetiva que compõe o universo humano, mas ela é responsável por configurar a realidade. De que forma o romance Úrsula configura a realidade? A saber, não apenas do ponto de vista interno, do próprio romance, pelo caráter inovador, como já mencionado, mas também do ponto de vista externo ao romance, já que o texto, dentro do horizonte de Ricoeur, deve ser compreendido como algo mais que uma simples estruturação de frases, pois ele exige que o paradigma da interpretação seja transposto para $\circ$ âmbito da ação, fazendo com que o texto e a vida se relacionem. O resgate das vozes silenciadas na literatura brasileira pode contribuir para a revisão da literatura canônica brasileira e para o redimensionamento da grande narrativa que é o discurso da própria história literária brasileira.

Já que a ficção é vista como um modo de auxiliar o indivíduo na tarefa de configurar sua própria existência, através da via da capacidade criativa, própria da atividade literária, afirmase que Maria Firmina dos Reis conseguiu configurar a sua própria existência. Partindo da questão autoral, deve-se ter em mente que ela é uma mulher maranhense, bastarda e mulata, escrevendo 
em pleno século XIX, um período de extrema segregação racial, social e de gênero. Um dos fatos que confirmam essa segregação é que a autora mantém o destino reservado às mulheres da época (as que ousavam escrever, apesar de todos os percalços, em um universo majoritariamente masculino e elitista); na maioria das vezes, essas mulheres acabavam omitindo os seus nomes das suas obras. Com Maria Firmina dos Reis não foi diferente: o romance Úrsula tem como assinatura apenas "uma maranhense". A escritora possui uma clara consciência que está de fora do universo literário, o que fica evidente já no prólogo do romance: mediante um diálogo direto com o leitor, a escritora apresenta-nos com lucidez o reconhecimento de que "pouco vale um romance escrito por uma mulher":

Mesquinho e humilde livro é este que vos apresento leitor. Sei que passará entre o indiferentismo glacial de uns e o riso mofador de outros, e ainda assim o dou a lume. Não é a vaidade de adquirir nome que me cega, nem o amor próprio de autor. Sei que pouco vale esse romance, porque escrito por uma mulher, e mulher brasileira, de educação acanhada e sem o trato e conversação dos homens ilustrados, que aconselham que discutam e que corrigem, com uma instrução misérrima, apenas conhecendo a língua de seus pais; e pouco lida, o seu cabedal intelectual é quase nulo. Então por que o publicas? Pergunta o leitor. Como uma tentativa, e mais ainda, por esse amor materno, que não tem limite, que tudo desculpa - os defeitos, os achaques, as deformidades do filho - e gosta de enfrentá-los e aparecer com ele em toda parte, mostrá-lo a todos os conhecidos e vê-lo mimado e acariciado. Não a desprezeis, antes amparai-nos seus incertos e titubeantes passos para assim dar alento à autora de seus dias, que talvez com essa proteção cultive mais o seu engenho, e venha a produzir cousa melhor, ou quando menos, sirva esse bom acolhimento de incentivo para outras, que com imaginação mais brilhante, com educação mais acurada, com instrução mais vasta e liberal tenham mais timidez do que nós. (REIS, 2004, p.14).

Maria Firmina, em seu prefácio, altera completamente a lógica da escrita no mundo ocidental - onde a metáfora que estrutura a relação texto/escritor é sempre a paternidade (o autor como o pai do texto); ela acaba por subverter essa ordem de uma forma radical ao alterar a relação autor/ texto, instaurando a metáfora da maternidade - "o amor materno" que a leva a publicar o romance.

O universo ficcional é chamado por Ricoeur de laboratório de forma, onde o ser humano ensaia configurações possíveis da ação para experimentar a sua consistência e a sua plausibilidade. Essa capacidade que o ser humano tem de experimentar (através da ficção) novos modos de ser é característica da imaginação produtora. Tal capacidade é exposta por Ricoeur através do conceito central ${ }^{7}$ da poética aristotélica-a mímesis. Ricoeur definirá a narrativa como uma composição de cunho prático, isso é, que imita a realidade, recriando-a. Não se trata de uma simples imitação, como na mímesis platônica. Partindo dessa ideia, as ações humanas podem ser compreendidas, pois somos capazes de descrevê-las a partir do que Ricoeur chama de uma "capacidade imaginativa". Ainda no âmbito da ficção, Ricoeur destaca que Aristóteles já tinha em mente a capacidade de (re)descrever a realidade, por parte do leitor (nesse caso, do espectador da tragédia grega). Essa (re)descrição consiste na transformação do leitor e na consequente transposição do plano do discurso para o plano da prática. ${ }^{8}$

Tendo em mente que a ficção narrativa altera a realidade cotidiana, entende-se como ocorre a articulação entre o mundo do texto e o mundo da vida, levando em consideração que a ficção narrativa "imita" a ação humana, uma vez que ela possui a mesma estruturação significante (de início, meio e fim) dada pela intriga. Diante dessa identificação, desse comum entre o texto e a ação, a ficção tem o poder de "refazer" a sua existência, isto é, o mundo do texto adentra o mundo da vida, transfigurando a própria realidade do indivíduo. O ser humano está entre esses dois horizontes: o da ficção e o da realidade; eles não são opostos, se compreendemos o mundo do texto como o mundo, conforme já falamos, em que podemos estar. Para Ricoeur, o mundo onde o leitor pode imaginar-se habitando. Descrever essa dinâmica é o papel da hermenêutica, como sugere o filósofo: "o papel da hermenêutica, dissemos nós, é duplo: reconstruir a dinâmica interna do texto e restituir a capacidade de a obra se projetar para fora na representação de um mundo que eu poderia habitar" (RICOEUR, 2000, p.43).

A dinâmica da hermenêutica descrita pelo filósofo pode ser bastante profícua para se pensar de que modo o reconhecimento da autoria feminina brasileira descortina um passado (sombrio) marcado pela violência e pela exclusão, mas também quais as possibilidades de novos horizontes para se pensar qual é o lugar que a autoria feminina pode reivindicar. A relevância

\footnotetext{
7 "A verdade do imaginário, a potência de revelação ontológica da poesia, eis o que, de minha parte, vejo na mímesis de Aristóteles. É por ela que a léxis é enfatizada e que os próprios desvios da metáfora pertencem à grande tarefa de dizer o que é. Mas a mímesis não significa apenas que todo discurso está no mundo. Ela não preserva apenas a função referencial do discurso poético. Enquanto mimesis, ela liga essa função referencial à revelação do Real como ato" (RICOEUR, 2000, p.219).

${ }^{8}$ A ancestralidade afro-brasileira possui um conteúdo cultural que possibilita pensar em uma transformação que tenha como pilares principais as noções de coletividade e solidariedade, com vistas à promoção de um mundo com melhores condições sociais para todos.
} 
histórica de Maria Firmina dos Reis começa a ser reconhecida somente depois de mais de cem anos da primeira publicação de suas obras. Um dos estudiosos responsáveis por essa visibilidade tardia foi José Nascimento Morais Filho (1975), através de Maria Firmina, fragmentos de uma vida. O interesse crescente pelo romance Úrsula não apenas configura a sua importância a partir dos aspectos já mencionados, mas também a partir da compreensão histórica, uma vez que ele também fornece uma "outra visão" a respeito da escravidão, configurando aquilo que Ravel chama de micro-história.

Quanto ao mais, parece-me evidente que a prática micro-histórica é hoje uma das mais vivas e uma das mais fecundas do ponto de vista analítico: a escolha essencial de uma escala de observação se baseia na convicção central de que ela oferece a possibilidade de enriquecer as significações dos processos históricos por meio de uma renovação radical das categorias interpretativas e de sua verificação experimental. (Jaques RAVEL, 1998, p.252).

No processo que contribui para o enriquecimento da compreensão de um contexto histórico, a personagem Mãe Susana é de suma importância. Entre o primeiro e o nono capítulos, Maria Firmina volta-se para a descrição dos outros personagens, a partir das narrativas em primeira pessoa. A composição da personagem Mãe Susana dá-se de modo singelo, mas algumas características merecem nossa atenção, visto que Maria Firmina dos Reis interrompe o fluxo do romance para que a fala de Mãe Susana entre em cena:

Susana chamava-se ela; trajava uma saia de grosseiro tecido de algodão preto, cuja orla chegava-lhe ao meio das pernas magras e descarnadas como todo o corpo: na cabeça tinha cingido um lenço encarnado e amarelo, que mal lhe ocultava as alvíssimas cãs. (REIS, 2004, p. 112).

O momento de interrupção da narrativa não parece ser aleatório, já que a voz de mãe Suzana surge exatamente no momento em que o personagem Túlio recebe a sua tão esperada carta de alforria. Nesse momento ilustrativo, Maria Firmina dos Reis contrapõe, na narrativa, duas vozes opostas e diferentes; além disso, o caráter "ideológico" do diálogo fica bastante evidente na medida em que a autora relativiza a carta de alforria como o símbolo e a concretude da liberdade. A abertura para o diálogo, a partir da repercussão das vozes dissonantes, possibilitanos pensar a tese acerca do "plurilinguismo no romance", de Mikhail Bakhtin:

O plurilinguismo, desta forma, penetra no romance, por assim dizer, em pessoa, e se materializa nele nas figuras das pessoas que falam, ou, então, servindo como um fundo ao diálogo determina a ressonância especial do discurso direto do romance. Disto se segue uma característica extraordinariamente importante do gênero romanesco: o homem no romance é essencialmente o homem que fala; o romance necessita de falantes que the tragam seu discurso original, sua linguagem. (Mikhail BAKHTIN, 1990, p. 134).

Na perspectiva das figuras das pessoas que falam, o "plurilinguismo no romance" configura aquilo que o autor entende como o discurso de outro, a saber: "o discurso de outrem na linguagem de outrem, que serve para refratar a expressão das intenções do autor" (1990, p.27). Bakhtin nomeia essa configuração de "palavra bivocal", uma vez que ela revela a intenção do personagem através da fala, de modo imediato, mas, além disso, a "bivocacidade" expressa também a intenção "semântica refratada por parte do autor" (1990, p.27).

Nesse discurso em que duas vozes coadunam, coexistem, relacionam-se ou se contrapõem, podemos entender a proposta de Bakhtin de modo mais amplo, não apenas a partir da existência de diferentes vozes e perspectivas no romance, mas também a possibilidade de pensarmos a pluralidade de forma mais abrangente, a saber, de diferentes discursos em jogo. Em Úrsula, visualizamos que a pluralidade de discursos é percebida a partir das visões distintas dos sujeitos escravizados e dos "senhores de escravo", por exemplo. O ponto central da proposta bakhtiniana é que o palco das relações dialógicas no interior do romance expõe o "dialogismo", a relação entre enunciado e mundo, sendo, desse modo, uma relação inseparável, revelando a compreensão que o discurso e a realidade sócio-histórica andam de mãos dadas no contexto da enunciação literária:

Todas estas linguagens, mesmo quando não são encarnadas num personagem, são concretizadas sobre um plano social e histórico mais ou menos objetivado (apenas uma linguagem que não se assemelha a outras pode ser não objetivada) e, por isso, atrás de todas elas, transparecem as imagens das pessoas que falam, em vestimentas concretas sociais e históricas. Para o gênero romanesco, não é a imagem do homem em si que é característica, mas justamente a imagem de sua linguagem. Mas para que esta linguagem se torne precisamente uma imagem de arte literária, deve se tornar discurso das bocas que falam, unirse à imagem do sujeito que fala. (BAKHTIN, 1990, p.137).

${ }^{9}$ O conceito de dialogismo está presente, primeiramente, em Marxismo e Filosofia da Linguagem (BAKHTIN, 1979 [1929]) e, depois, no seu estudo mais essencial de 1935, Questões de literatura e estética: a teoria do romance (1990). A teoria do romance concentra-se na noção de que o objeto principal do romance é o homem que fala e a sua fala. 
Na esteira da concepção de Bakhtin, o problema fundamental da análise da estilística do romance pode ser formulado a partir da imagem da linguagem: em Úrsula, a imagem de fala que merece destaque é a da narradora, Mãe Susana. É ela quem alerta Túlio da emboscada de pressupor que a carta de alforria fornecer-Ihe-ia a garantia da liberdade. A fala de Mãe Susana, direcionada a Túlio, revela o que Bakhtin (1990) compreende como um ponto de vista particular sobre o mundo, que almeja a uma significação social:

Tu! tu livre? ah não me iludas! - exclamou a velha africana abrindo uns grandes olhos. Meu filho, tu és já livre?...

- Iludi-la! - respondeu ele, rindo-se de felicidade - e para quê? Mãe Susana, graças à generosa alma deste mancebo sou hoje livre, livre como o pássaro, como as águas; livre como o éreis na vossa pátria.

Estas últimas palavras despertaram no coração da velha escrava uma recordação dolorosa; soltou um gemido magoado, curvou o fronte para a terra, e com ambas as mãos cobriu os olhos.

Túlio olhou-a com interesse; e começava a compreender-Ihe os pensamentos.

- Não se aflija - disse - Para que essas lágrimas? Ah! perdoe-me, eu despertei-lhe uma ideia bem triste! A africana limpou o rosto com as mãos, e um momento depois exclamou:

- Sim, para que estas lágrimas?!... Dizes bem! Elas são inúteis, meu Deus; mas é um tributo de saudade, que não posso deixar de render a tudo quanto me foi caro! Liberdade! liberdade... ah! eu a gozei na minha mocidade! - continuou Susana com amargura - Túlio, meu filho, ninguém a gozou mais ampla, não houve mulher alguma mais ditosa do que eu. Tranquila no seio da felicidade, via despontar o sol rutilante e ardente de meu país, e louca de prazer a essa hora matinal, em que tudo aí respira amor, eu corria às descarnadas e arenosas praias, e aí com minhas jovens companheiras, brincando alegres, com o sorriso nos lábios, a paz no coração, divagávamos em busca das mil conchinhas, que bordam as brancas areias daquelas vastas praias. Ah! meu filho! mais tarde deram-me em matrimônio a um homem, que amei como a luz dos meus olhos, e como penhor dessa união veio uma filha querida, em que me revia, em que tinha depositado todo o amor de minha alma: - uma filha que era minha vida, as minhas ambições, a minha suprema ventura, veio selar tão santa união. E esse país de minhas afeições, e esse esposo querido, essa filha tão extremamente amada, ah Túlio! tudo me obrigaram os bárbaros a deixar! Oh! tudo, tudo até a própria liberdade!

Estava extenuada de aflição, a dor era-lhe viva, e assoberbava-lhe o coração.

- Ah! Pelo céu! - exclamou o jovem negro enternecido- sim, pelo céu, para que essas recordações!?

- Não matam, meu filho. Se matassem, há muito que morrera, pois vivem comigo todas as horas. (REIS, 2004, p.115-116).

É através da passagem do diálogo entre o ingênuo Túlio, recém-alforriado, e a revelação das memórias dolorosas da velha Susana, que temos o confronto de dois enunciados distintos, revelando no plano da enunciação a "relação dialógica":

Dois enunciados distintos confrontados um com o outro, ignorando tudo um do outro, apenas ao tratar superficialmente um único e mesmo tema entabulam, inevitavelmente, uma relação dialógica entre si. Ficam em contato, no território de um tema comum, de um pensamento comum. [...] O autor de uma obra literária [...] cria um produto verbal que é um todo único (um enunciado). Porém ele a cria com enunciados heterogêneos, com enunciados do outro, a bem dizer. E até o discurso direto do autor é, conscientemente, preenchido de palavras do outro. (BAKHTIN, 1997, p. 342-343).

Ao analisarmos a fala da narradora, através do diálogo anterior, podemos afirmar que ela configura, na perspectiva da narratologia clássica, um tipo específico de narrador, que Gérard Genette, em Discurso da Narrativa (1995), designa como "narrador homodiegético". Considerando que a narradora não é a protagonista central do romance, mesmo assim, a personagem-narradora está presente na diegese. A sua participação se dá a partir do relato de acontecimentos inerentes ao desenlace da história (a história de amor entre Úrsula e Tancredo). Para Genette, a presença do "narrador homodiegético" pode ser variável, quando essa presença se confirma e ele próprio conta sua história. Logo, podemos afirmar que temos a recorrência do "narrador autodiegético", como no caso da personagem Mãe Susana, que narra suas próprias experiências passadas. Dentre as características principais desse tipo de narrador, está o relato de suas experiências próprias, onde ele é protagonista, a partir da fala na primeira pessoa gramatical. Carlos Reis e Ana Cristina Lopes definem o "narrador autodiegético" como "a entidade responsável por uma situação ou atitude narrativa específica: aquela em que o narrador da história relata as suas próprias experiências como personagem central da história" (REIS; LOPES, 1996, p. 251).

Mãe Susana, ao expor a sua experiência com a "real" liberdade em África, revela também a distância temporal estabelecida entre o passado e o presente temporal da história onde acontece a narração. A sua atitude narrativa revela, através de suas memórias, que já não é mais o mesmo "eu" de suas reminiscências da juventude, já que o panorama em jogo aqui é completamente diferente, tendo em vista que há uma distância temporal alarmante entre reconhecer-se como um 
"sujeito cativo", que teve a vida dilacerada, e uma pessoa que está em seu país de origem e pode usufruir da liberdade em seu sentido mais pleno.

[...] compreendemos a adoção de uma visão de mundo própria e distinta da do branco, sobretudo do branco racista, como superação da cópia de modelos europeus e de toda a assimilação cultural imposta como única via de expressão. Ao superar o discurso do colonizador em seus matizes passados e presentes, a perspectiva da negritude configura-se enquanto discurso da diferença e atua como elo importante dessa cadeia discursiva que irá configurar a afro-descendência na literatura brasileira. (DUARTE, 2008, p.13).

É através de Mãe Susana que somos arrebatados pelo submundo dos navios negreiros. Eduardo de Assis Duarte, um dos maiores especialistas em literatura afro-brasileira na academia brasileira, destaca que é essa a primeira passagem na literatura brasileira em que uma narrativa acerca da miséria e da crueldade dos navios negreiros é apresentada em um texto de prosa literária; como ele afirma: "esta é a primeira vez que o porão do navio negreiro aparece na literatura brasileira. Por mais que nossos escritores românticos combatessem a escravidão, antes de 1859, nenhum deles trouxe para seus leitores detalhes do tráfico" (DUARTE, 2014, p.57). O relato de Susana é dirigido a Túlio, escravo recém-alforriado; Mãe Susana lembra-o da impossibilidade de ser completamente livre em um contexto escravocrata. A liberdade, para Mãe Susana, é um conceito que só tem relevância em seu espaço originário, em África (de onde ela foi arrancada):

Tu! Tu livres? Ah não me iludas! - exclamou a velha africana abrindo uns grandes olhos. [...] Liberdade... eu gozei em minha mocidade!- continuou Susana com amargura. Túlio, meu filho, ninguém a gozou mais ampla, mulher alguma mais ditosa do que eu (REIS, 2004, p. 114).

[...] Ainda não tinha vencido cem braças de caminho, quando um assobio, que repercutiu nas matas, me veio orientar acerca do perigo iminente, que aí me aguardava. E logo dois homens apareceram, e amarraram-me com cordas. Era uma prisioneira - era uma escrava! Foi embalde que supliquei em nome da minha filha, que me restituíssem a liberdade: os bárbaros sorriam-se de minhas lágrimas, e olhavam-me sem compaixão. [...] Meteram-me a mim e a mais trezentos companheiros de infortúnio e de cativeiro no estreito e infecto porão de um navio. Trinta dias de cruéis tormentos, e de falta absoluta de tudo quanto é necessário à vida passamos nessa sepultura até que abordamos as praias brasileiras. [...] vimos morrer ao nosso lado muitos companheiros à falta de ar, de alimento e de água [...] é horrível pensar que criaturas humanas tratem seus semelhantes assim e que não lhes doa a consciência de levá-los à sepultura asfixiados e famintos. (REIS, 2004, p.117).

A voz marcante de Mãe Susana, que aconselha e revisita o seu mundo da vida a partir das lembranças dolorosas e desumanas, difere de todos os romances que envolvam a temática escravocrata, como, por exemplo, As Vítimas-algozes, de Joaquim Manuel Macedo (1991 [1869]), em que o autor configura o escravo como feio, malcriado e presunçoso. A própria linha justificativa para a defesa da abolição da escravidão presente na obra visa à proteção dos senhores de escravos, para que eles não se tornassem vítimas, e os escravos os "algozes". Já em Úrsula, não se encontra a carga semântica negativa dirigida aos personagens africanos e afrodescendentes escravizados. Pelo contrário, a autora inverte a lógica vigente, ao colocar o senhor de escravos como um vilão, a personificação de todo mal sobre a terra. Como afirma Eduardo Duarte, "o comendador compõe a figura sádica do senhor cruel que explora a mão de obra cativa até o limite de suas forças" (2004, p. 270).

Outra passagem que também merece destaque pelo contexto do século XIX é o momento em que a autora estabelece mais uma inversão dos valores vigentes, colocando o jovem branco em uma situação de gratidão para com o jovem negro.

Apesar da febre, que despontava, o cavaleiro começava a coordenar suas ideias, e as expressões do escravo, e os serviços que lhe prestara tocaram-lhe o mais fundo do coração. É que em seu coração ardiam sentimentos tão nobres e generosos que animavam a alma do jovem negro, por isso, num transporte de íntima e generosa gratidão, o mancebo, arrancando a luva, que lhe calçava a destra, estendeu a mão ao homem que o salvara. (REIS, 2004, p. 25).

A capacidade de fornecer ao indivíduo novas formas de realidade está presente na escrita de Maria Firmina dos Reis, principalmente no modo como ela configura o seu enredo e na maneira com que os personagens são construídos. Para Ricoeur, o que caracteriza essa capacidade de fornecer novas formas de realidade é a força heurística da ficção. É através dela que os seres poderão ensaiar novas formas de estar no mundo, através da reconfiguração de seus valores e de suas ideias. O caráter inovador do romance de Maria Firmina dos Reis, a partir do modo como ela redescreve a realidade, cumpre com uma das funções da ficção descritas por Ricoeur, já que o poder de redescrever a realidade se deve ao fato de ela ter, segundo Ricoeur, uma valência dupla:

[...] ela dirige-se para algures, mesmo para nenhuma parte; mas, porque designa o não-lugar em relação a toda realidade, pode visar indiretamente esta realidade, segundo aquilo a que eu gostaria de chamar um novo efeito de referência (como alguns falam de efeito de sentido). 
Este novo efeito da referência não é mais do que o poder da ficção de redescrever a realidade. (RICOEUR, 1989, p. 221).

É somente através da capacidade imaginativa apresentada pela ficção que os seres humanos, ao entrarem em contato com o mundo do texto, não estão restritos à busca infindável pelas intenções do autor, isto é, não se trata de encontrar em um determinado texto o que o autor pretende dizer. De acordo com Ricoeur, o texto possui certa autonomia, ou seja, possui uma independência em relação ao autor e ao contexto em que ele foi escrito. Dessa forma, diante de tal autonomia, o leitor está livre para buscar um mundo possível em que ele possa habitar. Assim, o reino da ficção, como exposto por Ricoeur, abre um leque de possibilidades para que os indivíduos possam nortear suas ações. As fábulas, as tragédias gregas e o romance, em suas diversas modalidades, configuram-se como ricos modelos de situações e de personagens, nas quais o ser humano pode encenar a si mesmo e voltar "transformado" ao mundo da vida. Para o filósofo, os livros não apenas apresentam as ideias de um determinado autor, mas, também, de certo modo, as ideias de um determinado período histórico. No que diz respeito ao romance Úrsula, esse aspecto fica bastante evidente, o que leva à compreensão de que é impossível esconjuntar, nesse caso, o romance de seu contexto. Maria Firmina dos Reis, com sua escrita inovadora, consegue ultrapassar não apenas o contextual histórico da época, mas também algumas das convenções românticas, bem como o próprio script narrativo do estilo literário em voga no período.

Para "re-pensar" a identidade literária nacional, torna-se imprescindível reescrever a história da literatura brasileira, partindo, especificamente, daquelas obras que foram deixadas de lado nos reconhecidos manuais de literatura, uma vez que reconhecemos que a formação da identidade como nação depende, em grande parte, do resgate memorialístico. O romance de Maria Firmina dos Reis traz a história de amor entre Úrsula, a personagem central, e Tancredo, tendo como pano de fundo a temática do período sombrio da escravidão no Brasil. A narrativa pretende recuperar esse período histórico, fazendo esforço para reinterpretá-lo pela ótica dos escravizados. Assim, Maria Firmina dos Reis, pela primeira vez na história da literatura brasileira, concede voz ativa e central a uma negra para descrever e recuperar essa memória a partir de sua própria condição. Algumas pesquisadoras têm refletido sobre a importância da pesquisa acerca de obras de autoria feminina, como, por exemplo, Rita Terezinha Schmidt (2008), ao considerar que um dos efeitos resultantes desses estudos seja a alteração de nossas percepções com relação ao passado, de maneira a desestruturar a conjectura dessa identidade, conduzindo-nos a uma reflexão sobre o que está em jogo nos processos de constituição dos cânones literários nacionais como lugares válidos e privilegiados de estruturação de projeções imaginárias, que sustentam as representações simbólicas da nacionalidade. Tais considerações levam-nos a considerar a história literária como um dos marcos referenciais da memória nacional, dado que funciona como uma narrativa que pretende retratar a memória e a identidade nacional.

Schmidt (2008) salienta duas questões inerentes à própria escrita feminina: a primeira, o âmbito social, que considera a atividade da escrita como uma função imprópria para a mulher; a segunda, uma depreciação da literatura de autoria feminina produzida no passado. Para Schmidt, esse repúdio seria um modo estratégico de controlar o campo literário a partir da conceitualização de literatura, definida, essencialmente, como palco das relações de poder, no qual ocorre a legitimação do aparato inseparável das elites culturais - o saber/poder -, resultando na assimilação do ponto de vista de classe, gênero e raça dominantes por parte da comunidade interpretativa. A evidência e o acesso às obras de autoria feminina no universo acadêmico não apenas contagiam o status da história cultural e literária, fazendo com que se possa questionar a hegemonia da literatura tradicional canônica, mas também problematizam a exclusão dessas vozes e representações no processo de constituição da identidade nacional brasileira, do ponto de vista da diferença de gênero, classe social e raça (SCHMIDT, 2011)

Edward Said (1990), crítico literário palestino, destaca o fato de que os estudos feministas (assim como os anti-imperialistas ou étnicos) proporcionam a desarticulação da perspectiva quando o ponto inicial de suas análises está centrado no direito de grupos marginalizados de se expressarem e de se representarem nos domínios políticos e intelectuais, dos quais normalmente são excluídos, e que usurpam suas funções de significação e representação, assim como falseiam suas realidades históricas. ${ }^{10}$ Além disso, de modo mais específico, busca-se analisar e problematizar como é retratada a própria mulher afro-brasileira.

\section{Parágrafo retratado}


Úrsula caracteriza a atitude política da escritora Maria Firmina dos Reis, na qual a ficção mostra-se como palco de denúncias, principalmente com relação às injustiças vivenciadas pelas mulheres e escravos no século XIX. De certo modo, a autora trata de modo ficcional de questões que dizem respeito à ética - a noção de humanidade (no caso do romance, uma irmandade possível entre brancos e negros).

\section{Considerações finais}

Partindo da premissa de que a narrativa afrodescendente ocorre historicamente pela exclusão, tanto do ponto de vista literário como do ponto de vista social, acreditamos que o resgate dessas autoras seja necessário e significativo, como ressalta Schmidt (2011), uma vez que o entrecruzamento de discurso, memória e identidade é de suma importância, visto que permite refletir sobre as representações desses sujeitos que recaíram no esquecimento. Para resgatar a identidade desses sujeitos, faz-se necessário tratar também de questões que permeiam a escrita afrodescendente, como, por exemplo, a ancestralidade, componente essencial para se analisar criticamente a história e, principalmente, as relações desiguais entre brancos e afrodescendentes no Brasil do século XIX. Essa perspectiva sugere-nos que as noções de solidariedade e de ancestralidade (Helena HIRATA, 2014) presentes na literatura afro-brasileira possuem um conteúdo cultural que possibilita pensar em uma transformação que tenha como pilares principais as noções de coletividade e solidariedade para a promoção de um mundo com condições sociais melhores.

Úrsula, de Maria Firmina dos Reis, o primeiro romance abolicionista brasileiro, traz consigo a problemática do racismo. Cabe aqui retomar a noção de racismo epistêmico desenvolvida por Elzahra Osman (2015). De acordo com Osman, o racismo inicia-se no momento em que se desconsideram os saberes que não pertencem ao mundo masculino, branco, heteronormativo e judaico-cristão. Consequentemente, as outras formas de saber de outros povos são desvalorizadas e consideradas inferiores. De que modo, ainda hoje, em pleno século XXI, é possível afirmar que a escrita feminina afro-descendente ainda sofre com o racismo epistêmico? Uma das respostas possíveis para essa questão é que o cânone literário brasileiro "oficial" não reconhece Úrsula, porém o mesmo não pode ser dito do cânone literário afro-brasileiro, tampouco do cânone literário de autoria feminina. Será que o fato de um romance ser importante para as duas tradições canônicas intranacionais e emergentes não é um fator significativo para que se reavalie Úrsula e o seu lugar na história da literatura brasileira "oficial"? Um dos argumentos favoráveis para a "reavaliação" do romance é a partir da fortuna crítica, já que a cada ano surgem novos artigos, dissertações e teses acadêmicas sobre a importância deste romance para a literatura brasileira, como, por exemplo, o trabalho de "resgate" realizado por Eduardo Assis Duarte (2004) e Algemira de Macêdo Mendes (2011). Maria Firmina dos Reis articula no interior do seu romance a tarefa exclusiva à literatura, segundo Ricoeur, a partir da unificação entre o mundo da vida e mundo do texto. Encontramos essa unificação em Úrsula, a partir de dois aspectos: a configuração de um mundo próprio presente no romance, e a capacidade que a narrativa tem de reconfigurar o mundo da vida, fornecendo a possibilidade de uma ressignificação da nossa identidade como uma comunidade literária nacional.

\section{Referências}

ARISTÓTELES. Poética. 3. ed. Tradução de Ana Maria Valente. São Paulo: Fundação Calouste Gulbenkian, 2008.

BAKHTIN, Mikhail. Marxismo e filosofia da linguagem: problemas fundamentais do método sociológico na ciência da linguagem. São Paulo: Hucitec, 1979 [1929].

BAKHTIN, Mikhail. "O discurso no romance". In: BAKHTIN, Mikhail. Questões de literatura e de estética: a teoria do romance. 2. ed. São Paulo: Hucitec, 1990. p.71-210.

BAKHTIN, Mikhail. Estética da criação verbal. 2. ed. Tradução de Maria Ermantina Galvão G. Pereira. São Paulo: Martins Fontes, 1997.

BUTLER, Judith. Relatar a si mesmo: crítica da violência ética. Tradução de Rogério Bettoni. Belo Horizonte: Autêntica, 2015.

COMPAGNON, Antoine. O demônio da teoria: Literatura e senso comum. Belo Horizonte: UFMG, 2014.

CORDÓN, Juan M. N. "Existencia y libertad: sobre la matriz ontológica del pensamiento de Paul Ricoeur". In: MARTINEZ, Tomás; CRESPO, Remédios A. (Eds.). Paul Ricoeur: los caminos de la interpretación. Barcelona: Editorial Anthropos, 1991. p. 145-182. 
DAVIES, Catherine. "Introduction". In: AVELLANEDA, Gertrudis Gómez de. Sab. Manchester: Manchester University Press, 2001. p. 1-28.

DUARTE, Eduardo de Assis. "Posfácio". In: REIS, Maria Firmina dos. Úrsula. 4. ed. Florianópolis: Mulheres; Belo Horizonte: PUC-Minas, 2004. p. 265-281.

DUARTE, Eduardo de Assis. "Literatura afro-brasileira: um conceito em construção". Estudos de Literatura Brasileira Contemporânea, n. 31, p. 11-23, jan./jun. 2008.

DUARTE, Eduardo de Assis. Literatura afro-brasileira (cem autores do século XVIII ao XXI). Rio de Janeiro: Pallas, 2014.

GENETTE, Gérard. Discurso da narrativa. Lisboa: Vega, 1995.

GUIMARÃES, Bernardo. A escrava Isaura. São Paulo: FTD Editora, 2011.

HIRATA, Helena. "Gênero, classe e raça: interseccionalidade e consubstancialidade das relações sociais". Tempo Social (USP), v. 26, n. 1, p. 61-73, 2014. Disponível em: http://www.revistas.usp.br/ts/ article/view/84979/87743. Acesso em: 20/07/2015.

LÓPEZ-LABOURDETTE, Adriana. "Prólogo". In: AVELLANEDA, Gertrudis Gómez de. Sab. Barcelona: Ediciones Universal, 2012. p. 7-13.

MACEDO, João Manuel de. As vítimas-algozes. 3. ed. São Paulo: Scipione, 1991 [1869].

MENDES, Algemira de Macêdo. "Maria Firmina dos Reis: uma voz na história da Literatura AfroBrasileira do século XIX". In: FERREIRA, Élio; MENDES, Algemira de Macêdo (Orgs.). Literatura afrodescendente: memória e construção de identidades. São Paulo: Quilombhoje, 2011. p. 2339.

MORAIS FILHO, José Nascimento. Maria Firmina: fragmentos de uma vida. São Luiz: COCSN, 1975.

MUZART, Zahidé Lupinacci. Escritoras brasileiras do século XIX: Antologia. Florianópolis: Editora Mulheres, 1999.

OSMAN, Elzahra. "Retóricas da descolonização do pensamento: projeto epistêmico islâmico feminista contra a colonialidade do saber". Problemata, v. 6, n. 1, p. 283-316, 2015. Disponível em: http://www.periodicos.ufpb.br/ojs/index.php/problemata/article/view/24244/13697. Acesso em: 01/10/2015.

PLATÃO. Sofista. Tradução de Jorge Paleikat e João Cruz Costa. São Paulo: Abril Cultural, 1972.

PLATÃO. A República. São Paulo: Martin Claret, 2000.

RACHELS, James. Os elementos da filosofia moral. São Paulo: Manole, 2006.

RAVEL, Jacques. Jogos de escalas: a experiência da micro-análise. Rio de Janeiro: FGV, 1998.

REIS, Carlos; LOPES, Ana Cristina M. Diccionario de narratología. Salamanca: Ediciones Colegio de España, 1996.

REIS, Maria Firmina dos. Úrsula. 4. ed. Florianópolis: Mulheres; Belo Horizonte: PUC-Minas, 2004.

RICOEUR, Paul. Do texto à ação: ensaios de hermenêutica II. Tradução de Alcino Cartaxo e Maria José Sarabando. Porto: Rés, 1989.

RICOEUR, Paul. A metáfora viva. Tradução de Dion Davi Macedo. São Paulo: Loyola, 2000.

SAID, Edward. Orientalismo: o Oriente como invenção do Ocidente. São Paulo: Companhia das Letras, 1990.

SCHMIDT, Rita Terezinha. "Quem reivindica a identidade?". Desenredo, Passo Fundo (UPF), v. 4, n. 1, p. 49-60, 2008.

SCHMIDT, Rita Terezinha. "Centro e margens". Estudos de Literatura Brasileira Contemporânea, Brasília (UnB), n. 32, p. 127-141, 2011. 
Mônica Saldanha Dalcol (iD) 0000-0003-0174-2957

Doutoranda em Estudos Literários pelo Programa de Pós-Graduação da Universidade Federal de Santa Maria.

Filósofa e mestre em Filosofia pelo Programa de Pós-Graduação em Filosofia da Universidade Federal de Santa Maria.

Universidade Federal de Santa Maria, Departamento de Letras Vernáculas

Av. Roraima, n. 1000 - Centro de Artes e Letras - Prédio 40A

Campus Universitário UFSM - Bairro Camobi

97105-900 - Santa Maria - RS

(55) 32208087 e (55) 32208480

dlvcal@gmail.com

www.ufsm.br/dlv

monica.dalcol@hotmail.com

Anselmo Peres Alós (iD 0000-0003-2062-2096

Doutor em Letras pela Universidade Federal do Rio Grande do Sul

Pós-doutor pelo Programa de Pós-Graduação em Letras da Universidade Federal de Pernambuco como bolsista do Plano Nacional de Pós-Doutoramento (PNPD/CAPES), sob supervisão do Prof. Dr. Roland Walter. Atualmente, é professor Adjunto III no Departamento de Letras Vernáculas da UFSM e Docente Permanente do Programa de Pós-Graduação em Letras dessa mesma instituição. Universidade Federal de Santa Maria, Departamento de Letras Vernáculas

Av. Roraima, n. 1000 - Centro de Artes e Letras - Prédio 40A

Campus Universitário UFSM - Bairro Camobi

97105-900 - Santa Maria - RS

(55) 32208087 e (55) 32208480

dlvcal@gmail.com

www.ufsm.br/dlv

anselmoperesalos@gmail.com

\section{COMO CITAR ESSE ARTIGO DE ACORDO COM AS NORMAS DA REVISTA}

DALCOL, Mônica Saldanha; ALÓs, Anselmo Peres. "O mundo da vida e o mundo do texto em Úrsula, de Maria Firmina dos Reis". Revista Estudos Feministas, Florianópolis, v. 27, n. 1, e50550, 2019.

\section{CONTRIBUIÇÃO DE AUTORIA}

Mônica Saldanha Dalcol - Concepção. Coleta de dados, Análise de dados, Elaboração do manuscrito, revisão e aprovação da versão final do trabalho

Anselmo Peres Alós - Concepção e elaboração do manuscrito. Coleta de dados Participação ativa da discussão dos resultados; Revisão e aprovação da versão final do trabalho

\section{FINANCIAMENTO}

Mônica Saldanha Dalcol - Bolsa CAPES - 2016- 2017

Anselmo Peres Alós - Bolsa de Produtividade em pesquisa CNPQ

\section{CONSENTIMENTO DE USO DE IMAGEM}

Não se aplica.

APROVAÇÃO DE COMITÊ DE ÉTICA EM PESQUISA

Não se aplica.

\section{CONFLITO DE INTERESSES}

Não houve conflitos. 


\section{LICENÇA DE USO}

Este artigo está licenciado sob a Licença Creative Commons CC-BY. Com essa licença você pode compartilhar, adaptar, criar para qualquer fim, desde que atribua a autoria da obra.

\section{HISTÓRICO}

Recebido em 14/05/2017

Reapresentado em 07/05/2018

Aprovado em 15/05/2018 